\title{
sciendo
}

\section{Age Management: What Can we Learn from High-End Luxury Fashion Designer with More than 50 Years of Working Experience?}

\author{
Barbara Grah ${ }^{1}$, Ema Perme ${ }^{2}$, Simon Colnar $^{1}$ and Sandra Penger ${ }^{1}$ \\ ${ }^{1}$ University of Ljubljana, School of Economics and Business, Kardeljeva ploščad 17, 1000 Ljubljana, Slovenia, \\ barbara.grah@ef.uni-lj.si (corresponding author) \\ ${ }^{2}$ Ministry of Education, Science and Sport, Republic of Slovenia, Masarykova 16, SI-1000 Ljubljana, Slovenia
}

\begin{abstract}
Background and Purpose: While the world population is aging, the aim of this study is to bring new knowledge into age management research by investigating the most important factors that encourage older employees to remain in the labour market longer, also after meeting the official retirement age, based on an in-depth qualitative case study of the high-end luxury fashion designer with more than 50 years of working experience.

Design/Methodology/Approach: We conducted an inductive case study in fashion industry. Specifically, our case study is build based on the content analysis of secondary data as well as an in-depth interview with the general manager in the fashion and high-end luxury industry in Slovenia.

Results: The proposed conceptual model shows key facets, as assigned overarching categories, namely-vitality, intrinsic motivation, adapting, lifelong learning, and positive emotions and therefore contributes to the age management phenomena. Within the presented case study, we found out that the selected facets are the most important factors for the encouragement to remain in the labor market and to ensure flexible retirement processes in dealing with the challenges of an aging population and workforce.

Conclusion: Our study contributes to the theory and practice of age management by narrowing our focus on the best practice from selected high-end luxury fashion industry designer in Slovenia. What can we learn from high-end luxury fashion designer with more than 50 years of working experience? As the presented case study cannot be generalized to population, the presented case contributes to the field of age management and empowers people to rethink and stay active after meeting the official retirement age.
\end{abstract}

Keywords: Adult learning; Older workers; Retirement; Age management; Fashion industry; Intrinsic motivation; Vitality; Slovenia

\section{Introduction}

European age structures are changing due to decreased fertility rate and increased life expectancy, which are altogether reflected in a decline of the younger population on one hand and rapid growth of the older population $(65+)$ on the other hand. In addition, according to Eurostat (2019b), at the end of 2018, in EU-28, there was a total of 512 million people, thereof $45+$ aged $47,33 \%$ and $40,10 \%$ of people aged $50+$. This represents a challenge to the sustainability of the existing pension system, which is also evident in increasing official retirement age throughout European Member states. Therefore, Europeans will have to work longer to achieve full retirement age.

However, not all Europeans are willing, or capable to work longer. It is well documented that with aging, several human functions decline, as for example human cognitive functions (Prakash et al, 2009), physical (motor) capacities (Lindberg et al., 2009) and humans encounter

Received: June 11, 2019; revised: October 30, 2019; accepted: November 7, 2019 
more visual problems (Bucur et al., 2005). In this article, we are focused on human willingness to work longer. By conducting a qualitative design, namely a business case study of Slovenian high-end fashion industry designer, we are deepening our understanding regarding the key factors that affect human willingness to work longer. Concretely, the research question we aim to answer is "What is/are the most important factor(s) of an older employee for the encouragement to remain in the labor market longer, after meeting the official retirement age?".

We structure our paper as follows. First, we focus on the literature review, where the first part is dedicated to understanding the aging and age management in the EU and Slovenia, meanwhile, the second part is focused on the fashion and high-end industries in the $\mathrm{EU}$, in order for a reader to understand its importance. After the literature review, we present the methodology applied, with the sub-chapters on study design, data collection, and content analysis. Within the results section, we firstly present the case study context, which is needed to fully understand the second sub-chapter, namely the presented case study of Slovenian fashion industry designer, enriched with several in-depth quotations. Lastly, we focus on discussion and conclusion, where case study conceptual model is presented, followed by concrete theoretical contributions, practical implications as well as study limitations.

\section{Literature Review}

\subsection{Age management}

Bloom et al. (2015) predict that until 2030, every country will experience the aging of the population. In the past six decades, countries all over the world had to deal with only a modest increase in the share of people aged 60 years and older, from $8.0 \%$ to $10.0 \%$. Authors Howdon and Rice (2018) express the concern that existing demographic pressures that are a consequence of population aging could result in a significant rise in public expenditures to unsustainable levels under existing financing arrangements and would thus represent a serious issue for national economies (Bloom et al., 2015). Population aging in the future will definitely and naturally require changes to existing labor (Bogataj, McDonnell \& Bogataj, 2015; 2016). Žnidaršič and Dimovski (2010) argue that one of the most discussed policy options is to encourage older workers to work longer, even after the age of 65 . Nowadays the perception of the majority of workforce member over the age of 55 is changing as they do not expect to retire until well after the historically determined retirement age (Dimovski et al., 2019). When discussing longer participation of older workforce on the labor market, Slovenia is particularly problematic as it is among the countries with the low- est employment rate of the age cohort 55+ years among employees. The actual employment rate of $55+$ years is $16.1 \%$, which is 3.7 percentage points below the share of the EU. According to publicly available data of Eurostat (2019a) for the third quarter of the year 2018, the highest share of employees in the 55+ age cohort is in Germany and is equal to $23.8 \%$ and the lowest share is in Luxemburg, where the $55+$ age cohort share is equal to $10.5 \%$.

The concept of age management deals with various organizational activities that aim to uphold labor supply, tackle the challenges of different generations, retain valuable knowledge of individuals when they retire, maintain the productivity of older workers and organize the whole retirement process (Grima, 2011; Brooke and Taylor, 2005). Dimovski and Žnidaršič (2006) add that age management could also be understood as an application of the science of aging into practice with the goal of helping people improve the quality of their lives in the aging process. Ilmarinen (2012) explains age management as an approach in organizations with eight main characteristics. First, it is aimed to support knowledge and awareness on the general topic of population aging. Second, it promotes fair attitudes towards older employees. Third, he highlights its importance as a core task and responsibility of managers and supervisors. Fourth, he emphasizes the importance of integrating age management into human resource policy. Fifth, it promotes the ability of everyone to work and to increase the productivity of all workers and sixth, it encourages lifelong learning. Seventh, it endorses the necessity of such a working environment that takes into account also the needs of older workers and last, it is of paramount importance to enable a safe and dignified transition to retirement. In a nutshell, Luz, Leite and Alvarelhao (2019) define age management as the integration of specific (human resource) management measures that are intended to face the challenge of population ageing, where the goal is to allow each and every individual to remain active and healthy (Žnidaršič \& Dimovski, 2009a; 2009b), regardless of their age. Whereas Walker (2005) defines five practices under the age management concept as a whole, namely recruitment (including exit at the end of the working career), training, development, and promotions, flexible working practice, ergonomics and job design (Bogataj et al., 2017; Bogataj et al., 2019; Calzavara et al., 2019) to avoid negative stress (Rožman, Griekevich, \& Tominc, 2019; F, 2008), learning and technology (Janežič, Dimovski \& Hodošček, 2018; Arh, Blažič \& Dimovski, 2012), and changing attitudes towards ageing workers.

In general, according to Hedge, Borman Lammlein (2006), there is a typical perception that the closer an older worker is to retirement, the less motivation he/she has to be excellent in their job. On the contrary, Kanfer and Ackerman (2004) argue that older workers' motivation must be examined in the context of lifespan development theory, where the aging process is understood as a dynamic interaction between different gains and losses. The authors go 
on to conclude, that based on theoretical understanding of adult development, there is no reason to strictly follow the perception that job motivation can only decline with age. They propose that job motivation of older workers can be understood as a combination of both the nature of their work and the criteria that determine how their performance is assessed. Moreover, Boumans, De Jong and Janssen (2011) prove that older workers are more driven by intrinsic rewards of their work (i.e. a challenging job task) and to a higher level than their younger colleagues. Similarly, van den Berg (2011) suggests that if an individual is under the impression that his/her job is internally rewarding, he/ she is more likely to continue working after he/she already reaches the proposed retirement age.

Van der Heijden et al. (2009) posit that barriers older workers face having been discussed in-depth, however, less is known about what makes them prosper and what keeps them to want to continue working beyond the legal retirement age. Hennekam (2017) discusses thriving, consisting of both vitality and learning as a promising concept in the management literature, aimed at explaining why older workers want to remain active participants in the labor market. In the era of population aging, gaining additional insight into what helps older workers excel at their job, might positively influence their labor participation rates and endorse their will to extend their professional career. Hennekam (2017) further suggests that a positive relationship between thriving and self-perceived employability exists. Employability is an integral concept for individuals since every single employee nowadays is more and more responsible for their own career path and to maintain his/her job security (Van der Heijden \& Bakker, 2011). Moreover, it is especially important to older workers as they are typically the first category of workers to be seen as redundant and often their skills are labeled as outdated (Van den Broeck et al., 2014). Previous research already established that self-perceived employability leads to better performance, more professional development, better health (Berntson \& Marklund, 2007) and higher wellbeing at work (De Cuyper et al., 2008), which are all important factors that enhance the possibility for older workers to remain active participants on the labor market.

Older workers may also be valuable in the role of mentors as Kram and Hall (1989) suggest that older employees are more inclined to help others through mentoring activities. Similarly, Ardichvili, Page, and Wentling (2003) posit that older employees were indeed motivated to participate in knowledge sharing activities and mentoring new colleagues, due to their need to give something back to the organization. Heisler and Bandow (2018) propose that one of the possible methods to engage older workers is to support them leveraging their existing knowledge and experience for mentoring and developing knowledge transfer initiatives. Moreover, positioning older workers as mentors to their younger colleagues is another possible solution to promote their task significance and to further accelerate the knowledge transfer process. Authors Lundberg and Marshallsay (2007) claim that older workers themselves typically argue that the most effective training methods are in-service, in-house, one-on-one and practically oriented training methodologies, preferably establishing older workers as role models and mentors.

Vasconcelos (2018) endorses the opinion that older workers can be seen as valuable organizational assets. Moreover, their knowledge and expertise are part of organizational wisdom capital that requires careful attention from organizations and their managers in terms of appropriate incentives and training in order for them to remain productive within the organization. Older workers typically possess meaningful knowledge and extremely important experience that enables organizations to perform better and even attract new young talents. Vasconcelos (2018) further reports that in his research participants acknowledged knowledge and experience as one of the most important benefits of older workers. Similarly, the European Foundation for the Improvement of Living and Working Conditions (2006) reports that many organizations already realize that professional and social skills of older employees accumulated through their working career represent a special asset. The younger generation cannot completely match such skills and experience and any organizational attempt to build up younger colleagues could produce significant additional costs and extensive education and training. Numerous older workers possess qualities such as accuracy, reliability and the ability to properly communicate. The premature loss of such skills and consequent failure to replace them could represent a big economic risk for almost any organization. Practical experience and research indicate that older employees that are properly integrated into the organization are in practice still highly productive. Moreover, experienced older workers are also the potential resource to fill the gap in personnel in specific fields that have become unattractive for the younger generation in recent years (European Foundation for the Improvement of Living and Working Conditions, 2006).

Population aging also intervenes in the field of relationships between generations and influences several fields in the socio-economical, political and cultural life. Consequently, there is a need to create stronger intergenerational ties and reduce age segregation. According to Veingerl Čič and Šarotar Žižek (2017), intergenerational cooperation and generational management at work are becoming practically a necessity in organizations if they want to retain the knowledge and experience of older generations and at the same time acquire and retain talented young colleagues. In organizations, intergenerational cooperation can also be done by working closely together, where an older and younger person are able to enhance their understanding of the dynamics and characteristics of intergenerational relations (Sibinski, Sipa \& Gorzen-Mitka, 2016). To conclude, Crumpacker and Crumpacker (2007) posit that intergenerational management is gaining in importance and recogni- 
tion as nowadays the workforce is more diverse than ever, especially in terms of age, race, gender, and ethnicity.

\subsection{Fashion and high-end industries in the EU}

The fashion and high-end industries represent European cultural heritage and expertise with 5 million people directly employed in the fashion value chain and over 1 million people employed in the high-end industries. These activities provide an important contribution to the EU economy (European Commission, 2019). The fashion and high-end industries are one of the most creative sectors in Europe, as they are present in the everyday life of millions of people and act as ambassadors of European values, such as culture, creativity, innovation, and craftsmanship of each particular country. Fashion and high-end industries form complex and interweaved business value chains from the design and manufacturing of fashion goods, for example as textiles, clothing, footwear, leather, jewellery, and other high-end goods. Despite the economic crisis, the fashion industry has managed to defend their position in the global market, according to European Commission (2019) report, this is mainly due to a move towards innovative, high added-value products and services, niche markets, and new business models. The fashion and high-end sector grew faster than the rest of the European economy during the crisis, recording double-digit growth in 2010 and 2011. It employs over 1 million people, exports over $60 \%$ of their production outside Europe, and accounts for $10 \%$ of all EU exports. Strengthening the long-term competitiveness of fashion and high-end industries of EU countries is part of the broader European Commission strategy for the re-industrialization of Europe, where this strategy outlines to increase the proportion of GDP generated by manufacturing to $20 \%$ by 2020 . Furthermore, trends in fashion and high-end industries in the EU show that increasing life expectancy together with falling birth rates influences the rapid aging of the workforce. Older workers, workers that are at or approaching the official retirement age, are the fastest-growing category of the workforce and one of the fastest-growing groups (Cappelli, 2014) in the overall Slovenian and European populations. Similarly, Cappelli
(2014) outlines that the percentage of the population aged $65+$, who are at serious risk of mortality or life-threatening illness, will grow by about $16 \%$ until 2035 , which means that there will also be a huge cohort of healthy individuals in that age group who want and need to work.

However, the fashion and high-end sectors face several challenges, including the increased prevalence of counterfeit goods, increasing shortages of skilled workers, and difficulties for fashion small and medium-sized enterprises to access finance. Due to pressures for change arising from trade liberalization, increasing external competition, consumer developments, technological advances, changes in production costs and environmental issues, these industries must continuously reinvent their business models (European Commission, 2019). According to the EC report, fashion companies are most often micro-enterprises with less than 10 employees, where we can find the highest concentration of fashion industry in Italy, Spain, Greece, Portugal, as well as newer EU countries, for example in Poland, Romania, Bulgaria, Hungary. The countries with the largest number of fashion distribution and retail companies are Italy, France, Poland, Germany, and the United Kingdom. European high-end fashion industry has a worldwide reputation, and $62 \%$ of all goods manufactured by European high-end brands are sold outside Europe. The value of European high-end exports is estimated at EUR 260 billion - about $10 \%$ of all EU exports.

According to Statista report (Statista, 2019), the revenue in the bags and accessories segment in EU amounts to 15,726 million USD in 2019, where the revenue growth is expected to show an annual growth rate of $8.6 \%$, resulting in a market volume of USD $\$ 21,882$ million by 2023 (Figure 1). In the year 2017 a share of $26.6 \%$ of users is $25-34$ years old in the EU fashion market (Figures 2 and 3).

According to our knowledge, no evidence exists on scientific contributions of age management practices in the fashion industry. Therefore, based on the above literature review, we designed our research question as follows:

R1: "What is/are the most important factor(s) of an older employee for the encouragement to remain in the labor market longer, after meeting the official retirement age?" 


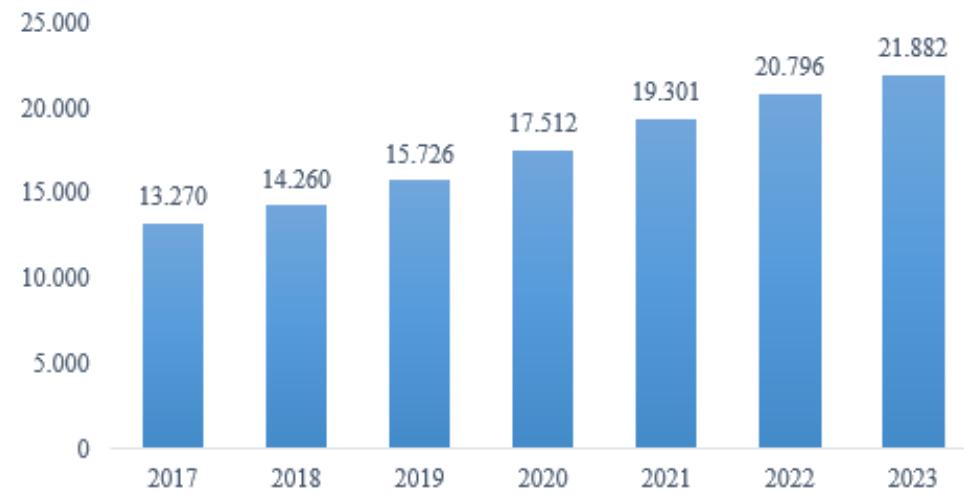

Figure 1: Revenue in the Bags \& Accessories fashion segment in EU in 2019 in million USD Source: Adapted from Statista (2019).

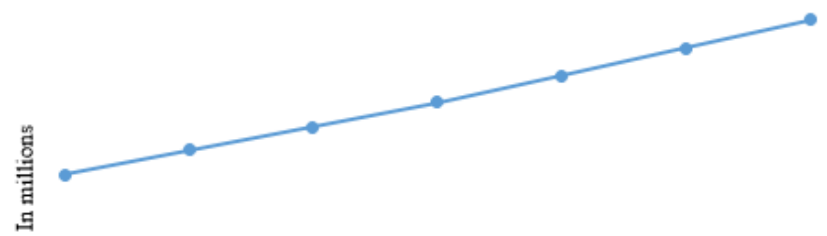

$\begin{array}{llllll}2017 & 2018 & 2019 & 2020 & 2021 & 2022\end{array}$

Figure 2: Amount of sales in the Bags \& Accessories fashion segment in EU in 2019 in million USD Source: Adapted from Statista (2019).

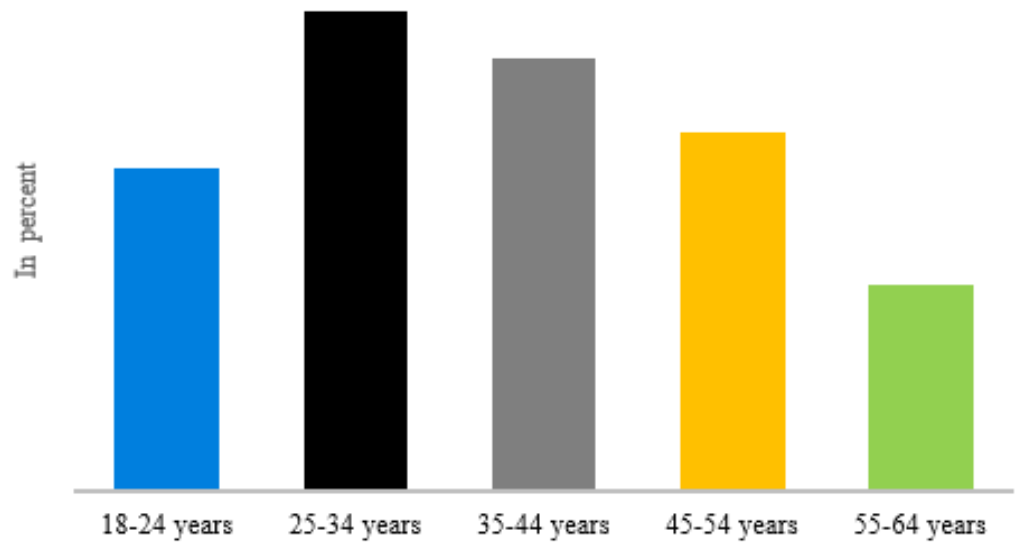

Figure 3: Amount of sales by age in the Bags \& Accessories segment in EU in 2019 in percentage Source: Adapted from Statista (2019). 


\section{Methodology}

\subsection{Study design}

Our case study empirically accesses age management concepts in Slovenia by offering inductive research and broader assessment of business impact in age management in Slovenia. Overall, our study sought to answer the following overarching research question: "What is/are the most important factor(s) of an older employee for the encouragement to remain in the labor market longer, after meeting the official retirement age?" More specifically, we sought to deepen the knowledge about age management impact and relative trend of aging in Europe. The single-case method is selected, as according to Yin (2003), even one case could be enough to generalize to theory. By conducting the business case from the fashion industry, we analyzed responses and experiences on age management best practices. The case from the high-end fashion industry has been selected for several reasons. First, according to our knowledge, there has been no scientific research yet, connecting high-end fashion industry and age management. Second, the high-end fashion industry is of high importance for the EU economy. Third, we have contacted the selected designer, one of the most recognized, if not the most recognized one in Slovenia, an EU member state, who was willing to collaborate on the study. It enabled us to collect in-depth, content-rich primary data to get an insight into our research question. It is a family-owned business, therefore, we have done the interview with the designer itself. The findings are presented based on the content analysis and qualitative research design, where the in-depth interview was employed with the general manager and business owner with more than 50-years of work experience in fashion and high-end luxury industry in Slovenia.

\subsection{Data collection}

The inductive case of the Slovenian high-end luxury fashion designer was conducted by analyzing primary data collected with the structured, in-depth qualitative interview and secondary data, collected from multiple sources for the purpose of triangulation. The inductive content analysis allows recognizing parts of the whole, connected to certain phenomena and its attributes (Peterlin et al., 2018). We conducted a search of the secondary archive in the period of 2016-2019 to obtain proof quotations reflecting Slovenian fashion industry designer attitudes toward work. Specifically, we did an online search, including Science Direct, Web of Knowledge, as well as relevant newspapers, magazines, and relevant internet webpages. These proofs were used to share information and represent a rich source of age management triangulation in the high-end luxury industry. In short, based on these research procedures, we are confident that 36 proof citations included in our research are the most relevant to support our research question. Furthermore, collected data were triangulated and evaluated for possible biases before inclusion in the analysis, as suggested by Charmaz (2011). To increase the reliability and validity of our qualitative assessment we triangulated primary data by theoretical triangulation through rich data contexts for understanding and interpreting quotations on age management phenomena in the case of the fashion industry in Slovenia.

\subsection{Content analysis}

We structured our analysis on age management by employing the method of a case study (Yin, 2003). In order to build a case study of high quality, the case study protocol was employed (Yin, 2003). Case study protocol included analyzing (1) the context of the case study on age management perspective in the high-end fashion industry in Slovenia, (2) ageing and age management in processes of ageing of Europe in the studied case, (3) intrinsic motivation of an older employees in the studied case, and (4) moderating effects of an ageing of population in Slovenia from specific implications from fashion industry. To analyze the collected data, content analysis is performed. The findings are presented in the form of assigned quotations from secondary sources as well as from primary in-depth interviews with the owner of the fashion store with more than 50-years of work experience in the high-end luxury fashion industry, in order to present the content-rich context.

\section{Results}

\subsection{The practice of Slovenian fashion industry designer}

We described results following the sequence of our research question: "What is/are the most important factor(s) of an older employee for the encouragement to remain in the labor market longer, after meeting the official retirement age?" To answer our research question, we first identified 31 proof quotations (Table 1) reflecting Slovenian fashion industry designer attitudes toward work and productivity. Results, regarding citing proof quotations, show that intrinsic motivation of an older employee is the most important for the encouragement to remain in the labor market longer, after meeting the official retirement age. They also have to stay healthy to perform work tasks, be positive and open to adult, lifelong learning. Results show 
that the future perspective of age management evaluation model, based on the practice of Slovenian fashion industry designer, should seek to empower employees' intrinsic motivation with the design and flexibility of adult learning programmers, as declared in recent OECD report on skills strategy implementation guidance for Slovenia of adult learning (OECD, 2018). Following the OECD (2018) diagnostic report the importance of improving adults' skills and effectively governing skills policy is of crucial importance for Slovenia to strengthen the overall conditions in adult learning and to address specific challenges in adult learning. Slovenia has developed an ambitious vision of learning for and throughout life. Lifelong learning is central to Slovenia's Development Strategy 2030 (OECD, 2018), where the strategy adopts a target of increasing participation in adult learning from $11,6 \%$ in 2016 to $19 \%$ by 2030. Motivating more adults to learn and employers to invest in training will be essential for achieving Slovenia's goal of raising participation in adult learning, as about half of Slovenia's adults (48\%) do not participate and do not want to participate in education and training (OECD, 2018). Motivation to learn is lowest among low-skill adults in Slovenia, where $57 \%$ of low proficiency adults in numeracy of literacy not participate, and no not want to participate in education and training. The EU recognizes promotion and raising awareness of adult learning as a priority, and has developed associated guidance and tools.

\subsection{The business case study on age management of Slovenian fashion industry designer $^{1}$}

"Ms. Marjeta Grošelj is a Slovenian designer of women's handbags. She celebrates her 50th anniversary of work in the fashion industry. Her handmade handbags [...] can be distinguished by their originality, exclusivity, durability and aesthetic perfection because they are made from the finest materials" (2TM, 2016).

Ms. Marjeta Grošelj opened her store 53 years ago when she was 21 . Since her youth, she was involved in fashion design, as her father and his brother owned Toko store, which produced leather goods (Pro Plus, 2016; Arsovski, 2016, Kontrec, n.d.), where she also collected her first working experiences during summer holidays (Delo, 2016; Arsovski, 2016, Kontrec, n.d.). Her parents were her role models, they were quite strict, however also very advanced (Pro Plus, 2016), and discipline, hard work without

\footnotetext{
${ }^{1}$ Authors express gratitude to Ms. Marjeta Grošelj, for her valuable time and openness to science research.
}

shortcuts and honesty were key values (Miše Miklavčič, 2018; Delo, 2016). The longitudinal visualization of business model development of Ms. Marjeta Grošelj, the Slovenian designer of high-end luxury women's handbags, is presented in Figure 4. All photos are received in second qualitative iteration with by Ms. Marjeta Grošelj, on October 19, 2019, where she, as the original owner of the photos, licensed the use of the images to the authors of this study for the purpose of scientific research and dissemination within this journal.

She studied at High school for design, where she also designed her first handbag (Arsovski, 2016, Pro Plus, 2016, Lovenjak, 2017). After high school, she participated in additional courses in London. When she started, it was difficult to get materials from abroad, but she managed to find creative solutions and her handbags stood out (Arsovski, 2016, Pro Plus, 2016, Kontrec, n.d.). She never takes orders for handbags, as she would lose her freedom and creativity to design it, and she does not reproduce her handbags, as each is unique (Pro Plus, 2016, Delo, 2016, Lovenjak, 2017, Grbin, n.d.). For her, it does not matter how much time a handbag production takes, what matters is whether she is satisfied with her final product. Her production is boutique, with emphasis on a personal touch and she wants to keep it that way.

Her handmade handbags can be distinguished by their originality, exclusivity, durability and aesthetic perfection because they are made from the finest materials. Marjeta Grošelj is rightly called an icon of fashion design in Slovenia (Education in Slovenia, 2016). She considers design as a true art. She does not only sell bags, rather, in her store, they have discussions about fashion (Lovenjak, 2017) and she also advises her customers, or as she calls them, her "guests" (Arsovski, 2016), and it might also happen that she discourages buying if she does not see perfect fit. It is more about the relationship, meeting people and artistic approach than classical sale (Pro Plus, 2016, Kontrec, n.d.). To the 50th anniversary of Marjeta Grošelj's career, the organizers of the Mercedes Benz Fashion Week have prepared an exhibition called "50 Years of Victories", where a selection of the best handbags by the world-famous Slovenian designer was presented (Education in Slovenia, 2016). During her professional career, Ms. Marjeta Grošelj received several awards, among others also a lifetime reward at autumn fashion week in 2013 (Pro Plus, 2016). 


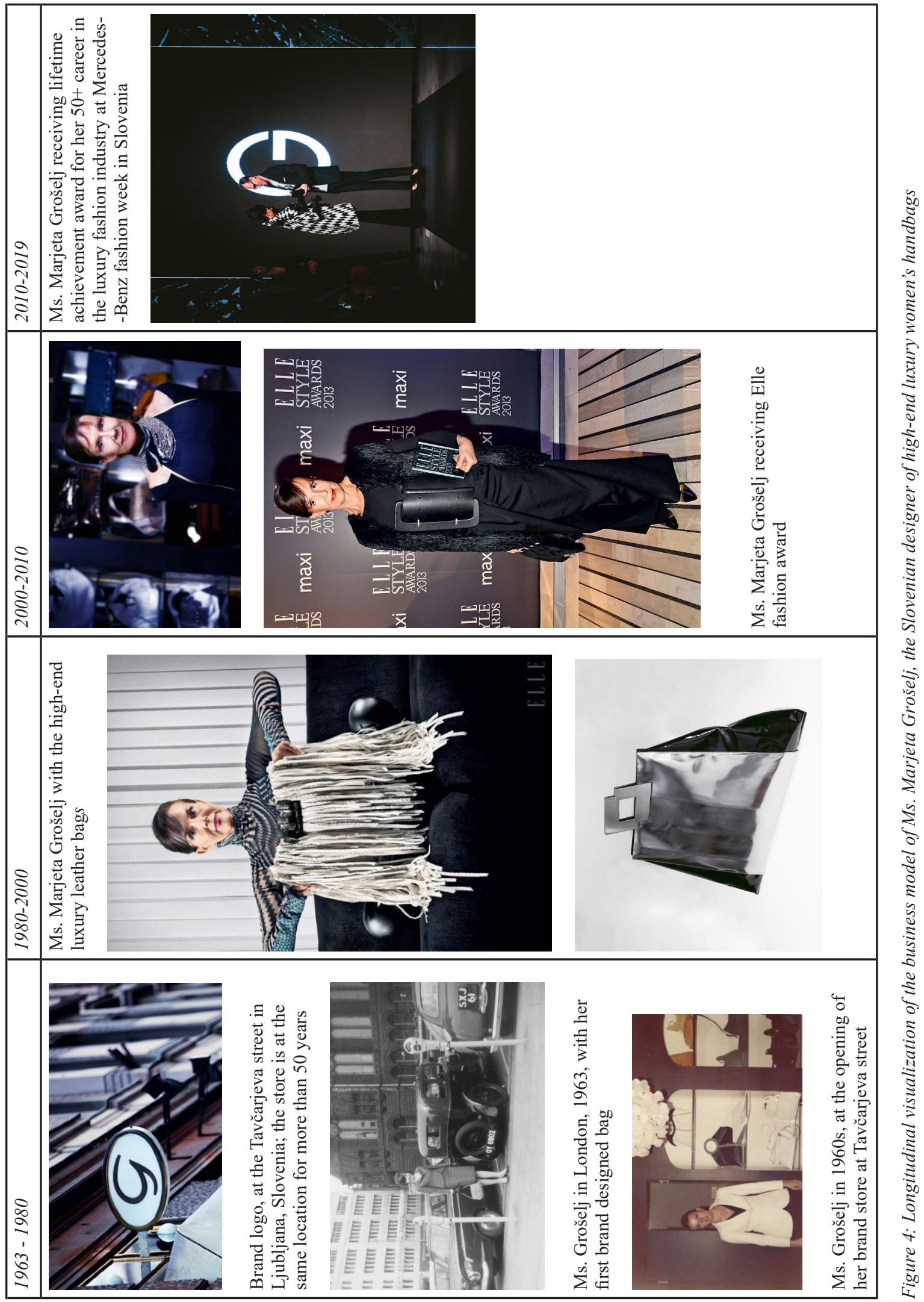


Table 1: Analysis of proof quotations reflecting Slovenian fashion industry designer attitudes toward work

\begin{tabular}{|c|c|c|}
\hline Number: & Selected quotations & Assigned code/ category \\
\hline Quotation 1 & $\begin{array}{l}\text { "How many bags she designed in all of these years, she does not } \\
\text { know, nevertheless she remembers everyone. She does not have her } \\
\text { favorite. They are all like her children. In every is a part of her." } \\
\text { (Pro Plus, 2016) }\end{array}$ & Intrinsic motivation \\
\hline Quotation 2 & $\begin{array}{l}\text { "She is constantly monitoring the fashion trends. From the very } \\
\text { beginning, her handbags are made of the best possible material. } \\
\text { From the worse she could not do it, therefore she has no low-pri- } \\
\text { ced lines. That's the way she is. When she gets inspiration for the } \\
\text { handbag, she sketches it quickly and then develops it further. First, } \\
\text { she focuses on design - which is the most important to her - then to } \\
\text { practicality." (Pro Plus, 2016) }\end{array}$ & Intrinsic motivation \\
\hline Quotation 3 & $\begin{array}{l}\text { "The appropriate material is the key to creating a handbag from } \\
\text { the paper. She acquires material on fairs, where she also always } \\
\text { explores what would be different, newer. She selects the material } \\
\text { visually and by touching it. She must feel it." (Pro Plus, 2016) }\end{array}$ & Intrinsic motivation \\
\hline Quotation 4 & $\begin{array}{l}\text { "Her handbags are fashionable, yet also durable. Like her store } \\
\text { on Tavčarjeva Street } 4, \text { which has been in the same location for } \\
50 \text { years. She opened it when } 21 \text { years old. She also creates in the } \\
\text { store. Everyday. This is her life. Even when she will not be working } \\
\text { anymore, she says she will be there." (Pro Plus, 2016) }\end{array}$ & Intrinsic motivation \\
\hline Quotation 5 & $\begin{array}{l}\text { "It is more about the relationship, socializing and an artistic ap- } \\
\text { proach than about the classical sales." (Pro Plus, 2016) }\end{array}$ & Intrinsic motivation \\
\hline Quotation 6 & $\begin{array}{l}\text { "She begins her day with physical exercise, then she comes to her } \\
\text { store. First, she goes to the studio, which is behind the shop where } \\
\text { she sketches. It is also where she is when there is no customer. Be- } \\
\text { tween } 12.30 \text { and 15.30, she closes the store. When her three sons } \\
\text { were smaller, she always came home at that time and cooked for } \\
\text { them and when they were babies she breastfed them. Matej says } \\
\text { that because they saw her three times a day-they did not even feel } \\
\text { that she was not with them, even though she worked whole days. } \\
\text { She returned to work six weeks after giving birth, while her mother, } \\
\text { aunt, and other family members took care of the children at the time } \\
\text { of her absence. From 15:30 to 19:00 she returns to the store and in } \\
\text { the evening a gym or something else follows. Many times she also } \\
\text { creates something in the evening. Matej says she can never be still. } \\
\text { She admits she would feel terrible without work. Designing is not } \\
\text { just her work. It's a lot more than just that. She enjoys in this busi- } \\
\text { ness. She lives with it. It is also her hobby, her air. If she wouldn't } \\
\text { have that, she might not existed anymore, says the designer." (Pro } \\
\text { Plus, 2016) }\end{array}$ & $\begin{array}{l}\text { Vitality } \\
\text { Intrinsic motivation }\end{array}$ \\
\hline Quotation 7 & $\begin{array}{l}\text { "She has no inheritor (yet). She does not even think about it, be- } \\
\text { cause she feels like she will be able to do it for another } 50 \text { years." } \\
\text { (Pro Plus, 2016) }\end{array}$ & Intrinsic motivation \\
\hline Quotation 8 & $\begin{array}{l}\text { "Also this year, the designer will spend her vacation at the same } \\
\text { place she is going for years. But also there she is not resting. She } \\
\text { cooks and makes plans for new handbags. And the latter is all that } \\
\text { she wants to do." (Pro Plus, 2016) }\end{array}$ & Intrinsic motivation \\
\hline
\end{tabular}


Table 1: Analysis of proof quotations reflecting Slovenian fashion industry designer attitudes toward work (continued)

\begin{tabular}{|c|c|c|}
\hline Quotation 9 & $\begin{array}{l}\text { "Marjeta Grošelj is regarded as an icon of Slovenian fashion desi- } \\
\text { gn, and during her long career, she received several international } \\
\text { awards for her work. Nowadays, Marjeta Grošelj handbags are a } \\
\text { well-established brand, a synonym for quality and creativity, which } \\
\text { in many of the outstanding works is already perceived as the arti- } \\
\text { stic creation." (Miše Miklavčič, 2018) }\end{array}$ & Intrinsic motivation \\
\hline Quotation 10 & $\begin{array}{l}\text { "Creating something new made me happy, if I did not start with } \\
\text { handbags, I would find something else creative. But when I star- } \\
\text { ted, it became the style of my life which I live also today. Although } \\
\text { I must admit, as a child, even more than a love to design, I re- } \\
\text { membered the values of the parents who believed and taught that } \\
\text { only honesty and hard work without shortcuts bring results" (Miše } \\
\text { Miklavčič, 2018) }\end{array}$ & Intrinsic motivation \\
\hline Quotation 11 & $\begin{array}{l}\text { "» This is my second home. At this address, my roots are firmly } \\
\text { rooted. Apart from the family, this is a space that means a lot to } \\
\text { me. It }>\text { s my second world where I still spend a lot of time. There } \\
\text { were always ideas born here. This is a space of positive energy and } \\
\text { a space in which I met many people, " says the host. »If you believe } \\
\text { it or not, after fifty years, I }>\text { m still happy to come back every day., } \\
\text { I am pleased that I can still do this, in which I sincerely enjoy. "” } \\
\text { (Delo, 2016) }\end{array}$ & Intrinsic motivation \\
\hline Quotation 12 & $\begin{array}{l}\text { "As children, we helped during every vacation. I gained a lot of } \\
\text { knowledge there and became a master in different fields. Although I } \\
\text { was thinking differently as a 15-year-old girl working in a factory, } \\
\text { out of love for fashion and design, a great love for handbags was } \\
\text { born. And this love still works today" (Delo, 2016) }\end{array}$ & Intrinsic motivation \\
\hline Quotation 13 & $\begin{array}{l}\text { "As I do not want to go to mass production, and my production } \\
\text { is boutique, I never really wanted to export to a foreign market. } \\
\text { All these unique pieces would lose their distinctive value" (Delo, } \\
\text { 2016) }\end{array}$ & Intrinsic motivation \\
\hline Quotation 14 & $\begin{array}{l}\text { "... I actually live day and night with handbags, and in the } \\
\text { workshop, I am also present when the product is made" (Delo, } \\
\text { 2016) }\end{array}$ & Intrinsic motivation \\
\hline Quotation 15 & $\begin{array}{l}\text { "You can never think what is hard and what isn't. Simply, you have } \\
\text { to do all that is in your power." (Arsovski, 2016) }\end{array}$ & Intrinsic motivation \\
\hline Quotation 16 & $\begin{array}{l}\text { "»Designing and making handbags is my life«, says proudly the } \\
\text { designer who bets on carefully selected materials and precision in } \\
\text { fabrication" (Arsovski, 2016) }\end{array}$ & Intrinsic motivation \\
\hline Quotation 17 & $\begin{array}{l}\text { "For over } 50 \text { years, Marjeta Grošelj has been transforming the } \\
\text { Slovenian fashion industry with her exceptional vision of the desi- } \\
\text { gn" (Arsovski, 2016) }\end{array}$ & Intrinsic motivation \\
\hline Quotation 18 & $\begin{array}{l}\text { "The times may change, but the work in the Marjeta Grošelj sho- } \\
\text { wroom is as it was five decades ago. A warm smile awaits you at } \\
\text { the sales desk, and the designer will take the time for each customer } \\
\text { and take her through the world of handbags with a unique appro- } \\
\text { ach." (Arsovski, 2016) }\end{array}$ & Intrinsic motivation \\
\hline Quotation 19 & $\begin{array}{l}\text { "I believe that things do not happen on their own and that your } \\
\text { work should be devised in the direction of what makes you happy } \\
\text { and fulfilled." (Grošelj, in Lovenjak, 2017) }\end{array}$ & Intrinsic motivation \\
\hline Quotation 20 & $\begin{array}{l}\text { "I have never thought much about business success, but primarily } \\
\text { that I can create and do something that pleases me and, on the } \\
\text { other hand, that people like." (Grošelj, in Lovenjak, 2017) }\end{array}$ & Intrinsic motivation \\
\hline
\end{tabular}


Table 1: Analysis of proof quotations reflecting Slovenian fashion industry designer attitudes toward work (continued)

\begin{tabular}{|c|c|c|}
\hline Quotation 21 & $\begin{array}{l}\text { "On my question of whether she had ever thought about retirement, } \\
\text { she is quiet for a while, and then sovereign says, "Ask me when I } \\
\text { will not be able to move."” (Lovenjak, 2017) }\end{array}$ & Intrinsic motivation \\
\hline Quotation 22 & $\begin{array}{l}\text { "In the conversation, I find out that she regularly goes to yoga } \\
\text { and aerobics, and occasionally to the fitness. "You know, vitality } \\
\text { is important at a later age. By doing so, you can greatly contribu- } \\
\text { te to your health, which is invaluable. Elegance is not only about } \\
\text { clothing, it is also about the behavior, about walking, movement. If } \\
\text { you are all stiff, it doesn't matter how you dress, but you probably } \\
\text { will not feel your best."" (Lovenjak, 2017) }\end{array}$ & Vitality \\
\hline Quotation 23 & $\begin{array}{l}\text { "When I ask her about her age, she says without reservation that } \\
\text { she has } 72 \text { years. "You know, I do not feel that old at all. Years do } \\
\text { not mean anything to me. Someone can be old at forty if he feels } \\
\text { so. My advice is movement. Of course, if you're healthy. You need } \\
\text { to take care of your body. This is also a very good antidepressant." } \\
\text { She adds: "Internal balance, a lot of positive energy and a little of } \\
\text { the stress." And a lot of laughing? "Of course. "In conclusions: } \\
\text { "Laugh has healing effects and above all, it costs nothing."" } \\
\text { (Lovenjak, 2017) }\end{array}$ & $\begin{array}{l}\text { Vitality } \\
\text { Positive emotions }\end{array}$ \\
\hline Quotation 24 & $\begin{array}{l}\text { "She opened her store on Tavčarjeva street in the center of Ljubl- } \\
\text { jana at the age of only 21, and although in September, she celebra- } \\
\text { ted } 45 \text { years of operation, she doesn't want even to hear about the } \\
\text { retirement. On the contrary, she says she will work as long as she } \\
\text { will be able to." (Kontrec, n.d.) }\end{array}$ & Intrinsic motivation \\
\hline Quotation 25 & $\begin{array}{l}\text { "She says she sees the key to her success in living for her work." } \\
\text { (Kontrec, n.d.) }\end{array}$ & Intrinsic motivation \\
\hline Quotation 26 & $\begin{array}{l}\text { "If we had stores all over the world, this would not have been pos- } \\
\text { sible. I do almost everything in the store - I am a designer, a con- } \\
\text { sultant, I create, I clean so that I never get bored when I'm there all } \\
\text { day." (Kontrec, n.d.) }\end{array}$ & Intrinsic motivation \\
\hline Quotation 27 & $\begin{array}{l}\text { "Nevertheless, she never gets tired of her work, which is precisely } \\
\text { why she doesn't want to even hear a word retirement." (Kontrec, } \\
\text { n.d.) }\end{array}$ & Intrinsic motivation \\
\hline Quotation 28 & $\begin{array}{l}\text { "Then what would I do with all the ideas I have in my head? (lau- } \\
\text { ghter) I will work until I can physically manage it, but even then I } \\
\text { can work from home. I could say that my work is a kind of addic- } \\
\text { tion, without which I cannot imagine my everyday life, I simply } \\
\text { enjoy it." (Kontrec, n.d.) }\end{array}$ & Intrinsic motivation \\
\hline Quotation 29 & $\begin{array}{l}\text { "We always like to remember a nice era and beautiful things, for } \\
\text { which I am grateful. This is my breathing, it's my life. If you do } \\
\text { something you do not enjoy, it is difficult to achieve fifty years of } \\
\text { career. I live with this and enjoy it." (Grošelj, in Grbin, n.d.) }\end{array}$ & Intrinsic motivation \\
\hline Quotation 30 & $\begin{array}{l}\text { "Once you accept that life is continuous learning, you are able to } \\
\text { deal with all situations and you look at all challenges as an oppor- } \\
\text { tunity for growth. In short, no (laughter). It's my life, I did not think } \\
\text { about quitting." (Grošelj, in Grbin, n.d.) }\end{array}$ & $\begin{array}{l}\text { Lifelong learning } \\
\text { Intrinsic motivation }\end{array}$ \\
\hline Quotation 31 & $\begin{array}{l}\text { "Marjeta Grošelj is not going to retire. She says that she will conti- } \\
\text { nue designing handbags for as long as her health permits because } \\
\text { she has more than enough ideas. "The ingenuity knows no end. The } \\
\text { work becomes easier with years, because the more you know, the } \\
\text { more you trust yourself."" (2TM, 2016) }\end{array}$ & $\begin{array}{l}\text { Vitality } \\
\text { Intrinsic motivation }\end{array}$ \\
\hline
\end{tabular}


Table 2: Analysis of an in-depth interview with Ms. Marjeta Grošelj on age-management

\begin{tabular}{|c|c|c|}
\hline Number & Primary data & Assigned codel category \\
\hline $\begin{array}{l}\text { Question 1: Your } \\
\text { unique bags have } \\
\text { an enviable, } \\
\text { over } 50 \text {-years } \\
\text { tradition. What is } \\
\text { making you stay } \\
\text { in your business, } \\
\text { designing unique } \\
\text { bags, although } \\
\text { you have already } \\
\text { met the retirement } \\
\text { conditions? }\end{array}$ & $\begin{array}{l}\text { "Surely vitality! Of course, passion and love of design are defining } \\
\text { my lifestyle, but creating without vitality would not be possible - } \\
\text { let alone fun. In some respects, I feel significantly better today } \\
\text { than } 15 \text { years ago. When, for example, I get up in the morning, } \\
\text { backbone does not hurt me anymore, for which I can thank re- } \\
\text { gular yoga and aerobics classes. It is important that vitality also } \\
\text { becomes a lifestyle - that it becomes a habit, a routine, something } \\
\text { without which it is difficult to live for us. As long as we are alive, } \\
\text { we have a duty and an opportunity, as much it is, of course, in our } \\
\text { power, to care for our own quality - that's why old ages are more } \\
\text { pleasant. Let me add that regarding vitality, I am not thinking only } \\
\text { of the physical condition, but also of the vitality of the mind. With } \\
\text { the accessibility and progress of technology, the world is changing } \\
\text { rapidly, and if you do not follow the trends, you are out quickly. } \\
\text { That is why I like to follow and listen to the younger generations, } \\
\text { who have been born with new technology and have a fresh, un- } \\
\text { burdened view of the world - they know their world and have the } \\
\text { energy that is not yet limited by seriousness and social expecta- } \\
\text { tions that can hinder their passion and creativity." (Grošelj, 2019) }\end{array}$ & Vitality \\
\hline $\begin{array}{l}\text { Question 2: De- } \\
\text { signing handbags } \\
\text { is what motivates } \\
\text { and impresses you } \\
\text { all the way from } \\
\text { your childhood, } \\
\text { from a family } \\
\text { tradition. Europe } \\
\text { is on the era of } \\
\text { extending working } \\
\text { lives. What do you } \\
\text { consider important } \\
\text { to motivate older } \\
\text { employees to stay } \\
\text { in the labor market } \\
\text { for a longer period } \\
\text { of time? What is it } \\
\text { that gives you such } \\
\text { a momentum for } \\
\text { creation? }\end{array}$ & $\begin{array}{l}\text { If you do not want your work to be a burden, you have to find out } \\
\text { what you are doing with passion, with all your heart, and what in } \\
\text { fact represents your hobby, which makes you learn and stay up- } \\
\text {-to-date. Then, too, stress is more positive, and this kind of work } \\
\text { can certainly be done for a longer time period. Again, we must } \\
\text { not forget the vitality - if we are burned, if we are afraid we will } \\
\text { lose our job, if we insist working, because we may be afraid of low } \\
\text { pension income, or if a cooperation with the younger is stressful, } \\
\text { then we certainly are not happy in the workplace and we do not } \\
\text { create enough added value in the environment in which we ope- } \\
\text { rate. We, the elderly need to acknowledge, understand and admit } \\
\text { that the world is moving forward, and that despite our knowled- } \\
\text { ge and experiences, we must be prepared to gain new knowledge } \\
\text { and listen to younger, if we want to keep up with our pace. We } \\
\text { have to be prepared to think "naughty", without prejudice, and } \\
\text { not relying solely on our past experiences. We need to find an in- } \\
\text { trinsic motivation for this. I personally do not feel old, and I'm } \\
\text { working on it to feel that way as long as possible. I believe that } \\
\text { if we do not know how to motivate ourselves intrinsically, also } \\
\text { external motivation in the form of various incentives, whether in } \\
\text { the form of targeted education, financial allowances, etc., does } \\
\text { not help much. By extending the working life, vitality is even more } \\
\text { important than before. }\end{array}$ & $\begin{array}{l}\text { Intrinsic motivation } \\
\text { Positive emotions } \\
\text { Vitality } \\
\text { Lifelong learning }\end{array}$ \\
\hline
\end{tabular}


Table 2: Analysis of an in-depth interview with Ms. Marjeta Grošelj on age-management (continued)

\begin{tabular}{|c|c|c|}
\hline $\begin{array}{l}\text { Question 3: How } \\
\text { you feel the deve- } \\
\text { lopment of tech- } \\
\text { nologies, e.g. the } \\
\text { way of designing } \\
\text { bags or your work, } \\
\text { in your business in } \\
\text { the luxury leather } \\
\text { goods/bags indu- } \\
\text { stry? How did you } \\
\text { adjust to it? }\end{array}$ & $\begin{array}{l}\text { My best technology has been and still are people. My employees } \\
\text { are the masters of their craft - every stitch, every hammer blow, } \\
\text { and every bending of leather reflects the knowledge and unique- } \\
\text { ness of each one. I am proud that after the rapid introduction of } \\
\text { massiveness, the market is returning to its basics, and also appre- } \\
\text { ciates artistic creation - the uniqueness with the soul, where there } \\
\text { is not focus on quantities, but the quality and longevity, behind } \\
\text { which stands a human of many talents and experiences. Although } \\
\text { the crafts work in many areas is going to extinct, in the future, } \\
\text { those who will be successfully preserved, or the ones who will } \\
\text { preserve the tradition, knowledge of previous generations and add } \\
\text { their own touch, will be extremely sought after and revered due } \\
\text { to rarity. } \\
\text { I am adapting to changing circumstances through the way I work, } \\
\text { by staying faithful to myself. I do not deviate from some of the } \\
\text { principles: the quality of the work done, the fair attitude towards } \\
\text { the employees and the payment of their work, the cultivation of } \\
\text { long-term relationships and the building of entrepreneurship thro- } \\
\text { ugh creativity, and not the other way around. }\end{array}$ & Intrinsic motivation \\
\hline $\begin{array}{l}\text { Question 4: In } \\
\text { your opinion, } \\
\text { how has the labor } \\
\text { market changed, } \\
\text { in respect of your } \\
\text { experiences in the } \\
\text { high-end fashion } \\
\text { industry for more } \\
\text { than } 50 \text { years of } \\
\text { work experien- } \\
\text { ce (duration of } \\
\text { employment, } \\
\text { availability of } \\
\text { jobs, ...)? }\end{array}$ & $\begin{array}{l}\text { There are plenty of changes, but if we are honest, it's natural - ask } \\
\text { for example people with a long enough "beard", about the selec- } \\
\text { tion of products in stores } 50 \text { years ago, about the TVs, how many } \\
\text { programs were broadcasted, what it meant to go abroad and how } \\
\text { many and what types of cars were driven on the roads at the time. } \\
\text { In the past, people have been able to spend their whole working } \\
\text { period in the same job, but today the probability of doing so is } \\
\text { much smaller - I'm trying that my employees would want to achie- } \\
\text { ve their full retirement age with me and I'm happy that in over } 50 \\
\text { years the vast majority of my employees really stayed up to "pen- } \\
\text { sion". Otherwise - regardless of age, we have to adapt to trends, } \\
\text { as it is not working in the opposite direction. We are again talking } \\
\text { about the flexibility and willingness to learn and change the deep- } \\
\text {-rooted mental maps. Regarding the availability of employment, } \\
\text { it is always so that you are employable if the market needs your } \\
\text { knowledge and experiences and if you are able to demonstrate it } \\
\text { at the right time and in the right way. }\end{array}$ & Adapting, lifelong learning \\
\hline
\end{tabular}


Table 2: Analysis of an in-depth interview with Ms. Marjeta Grošelj on age-management (continued)

Question 5: The
design of your
bags is not just
your work, but
the way you live,
as you say, this
is the air that you
breathe. Where
do you see the
benefits of older
employees for
the company,
business? How
can those be better
used by the com-
panies?

The elderly usually have a lot of knowledge and even more experiences. In the appropriate way, they can be excellent mentors to young people - not so much (of course also) at the business, as at the life, experience level. They can do a lot with mentoring, they can also accelerate progress, as the younger ones with proper work with a mentor do not repeat the same mistakes, and consequently, they learn more quickly and have a better basis for discovering new skills. Such intergenerational solidarity, if I can name it like this, is undoubtedly beneficial to society and businesses. In addition, the elderly may also be appreciated experts themselves, and it would be at least unfair to forget to note the added value of the elderly in the work process. Only, they should not lose their vital energy. Although it is good to be aware that in time, roles are changing - it is advisable for older experts to focus more on the role of counselors for young people, and those, who still have a lot of energy and fewer scars, should create, on the wings of experiences and "shortcuts", for future generations. In companies, this could be formalized, in order to raise the awareness of the importance of mentoring and, at the same time, the value of the elderly. Considering the fact that, on average, we live longer and the share of the elderly in society is increasing, which poses more burden on national finances, it would be reasonable to consider the national program, the package of systemic measures by decision-makers, to take care of active ageing at the various levels, the one that contributes and is not primarily a "burden" (e.g. health prevention, encouraging entrepreneurial thinking, educational programs/ qualifications of the elderly with respect to the profession by involving younger "working" mentors, the possibility of working after the retirement, etc.).
Lifelong learning, knowledge transfer

Vitality 


\section{Findings and conclusion}

\subsection{Case study conceptual model development - best practice case of Ms. Marjeta Grošelj, high-end fashion designer on age management}

Our findings section is organized to correspond to Table 1 and Table 2, which depict the content analysis model that emerged from collected secondary data and an in-depth interview with Ms. Marjeta Grošelj on age-management practice and experience. Based on the content analysis of data collected on the high-end fashion designer, Ms. Marjeta Grošelj, we develop the conceptual model (as presented in Figure 5) that describes her business model. The conceptual model provides insights from single case analysis and cannot be generalized to the population. The conceptual model shows key facets, as assigned overarching categories, namely-vitality, intrinsic motivation, adapting, lifelong learning, and positive emotions, of how Ms. Marjeta Grošelj, a business owner in high-end fashion industry intertwines her success and therefore a contribution to an age management phenomena. Specifically, our case study outlines, that Mr. Marjeta Grošelj expressed positive discrete emotions and organizational behavior facets, such as positive emotion, vitality, intrinsic motivation, and lifelong learning, as factors that helped her to be engaged in her job as well as willing to remain in the labor market longer, also after meeting the official retirement age. We also see the overlaps of the presented phenomena illustrating the interplay and/or simultaneity of lifelong experiences of the family owner, Ms. Grošelj that contributed to her age management paradigm. Findings of our case study are in line with recommendations posited by Shu (2015) that intrinsic motivation fosters the positive relationship between leadership and work engagement and consequently to age management.

Based on collected and analyzed data, we developed the conceptual model of her lifelong approach and her experiences on age management phenomena by isolating overarching facets for managing the complexity of longer living in everyday life. With our case, we contributed to the age management concept by presenting the in-depth qualitative case study with Ms. Marjeta Grošelj. Our findings are in line with recommendation cited by Businesseurocape report (2012) that states that among the most effective ways of enabling the extension of working lives and supporting internal and external flexibility for workers is through policies which maintain employability and adaptability, outlining three key facets: (1) Maintaining high levels of intrinsic motivation; (2) Safeguarding health and safety at the workplace, and (3) ensuring productivity and adaptability by updating skills throughout an individual's working career. Intrinsic motivation takes a hedonic perspective by emphasizing pleasure and enjoyment as drivers of effort, whereas prosocial motivation takes a eudaimonic perspective by emphasizing meaning and purpose as drivers of effort (Kahn, 1990). For intrinsically motivated individuals, the effort is based on interest and enjoyment; for prosocially motivated individuals, effort is based on a desire to benefit others (Grant, 2008). When intrinsic motivation is high, prosocial motivation is characterized by identified regulation: employees feel that completing their tasks is beneficial to their own self-selected goals, as they enjoy the process of working and value the outcome of helping others. In the absence of intrinsic motivation, however, prosocial motivation may not be sufficient to enhance persistence, performance, and productivity (Grant, 2008).

\subsection{Theoretical contributions}

We believe that our steps, presented in the single case study, towards active aging and empowered lifelong learning will be followed by further theoretical and empirical work. The theoretical contributions of the present study are multidimensional. First, our findings show important theoretical implications for researchers, studying age management phenomena in the age of aging of the European population, based on our inductive business case study of Slovenian luxury fashion designer, Ms. Grošelj.

Second, the key theoretical contributions are to be found in the conducted unique business interview itself, which adds to the literature of the age management best practices. Our study contributes to the theory of age management by narrowing our focus on the best practice from selected fashion industry designer in Slovenia.

The third theoretical contribution is to be found in the connection of the age management and the employee's perspective as our case is singe case unit and cannot be generalized, but we the presented employee perspective, analyzed at individual level, contributed to theory presenting individual level cases on human resource policies in the contemporary aging society. The presented business case from the high-end fashion industry overcomes the perceptions and limitations of the existing age management practices of older workers by expanding its scope from the luxury and high-end industry. We, therefore, contribute to the emerging debate on aging in Europe, by showing the single best practice example from luxury high-end industry in Slovenia. Our case presented contributes to the age management approaches, presenting a positive life story that can contribute to further cases and empirical investigations, as employees stay longer in their jobs and therefore become self-convinced, transfer knowledge and skills for their own benefit, organization, and society.

Public agencies and providers could engage end-users 
more systematically in the design of adult learning services to ensure they better meet users' needs and help improve participation in adult learning in the age of aging of Europe. With our good practice on age management in the Slovenian fashion industry, we have examined the critical issue of adult learning and motivation of older employees after meeting the retirement age. Hence, this case mirrors what organizations face in the age of aging of the population in Europe due to the demographic trends as they grapple with the age/employment paradox. Our good practice business case study shows deeper insight into age management paradox in Slovenia, based on the presented single life story of successful Slovenian luxury designer. Our study contributes by demonstrating how age management at the business/organizational level is managed by Ms. Marjeta Grošelj, outlining positive emotions, intrinsic motivation, lifelong learning, and vitality as overarching facets.

\subsection{Practical implications}

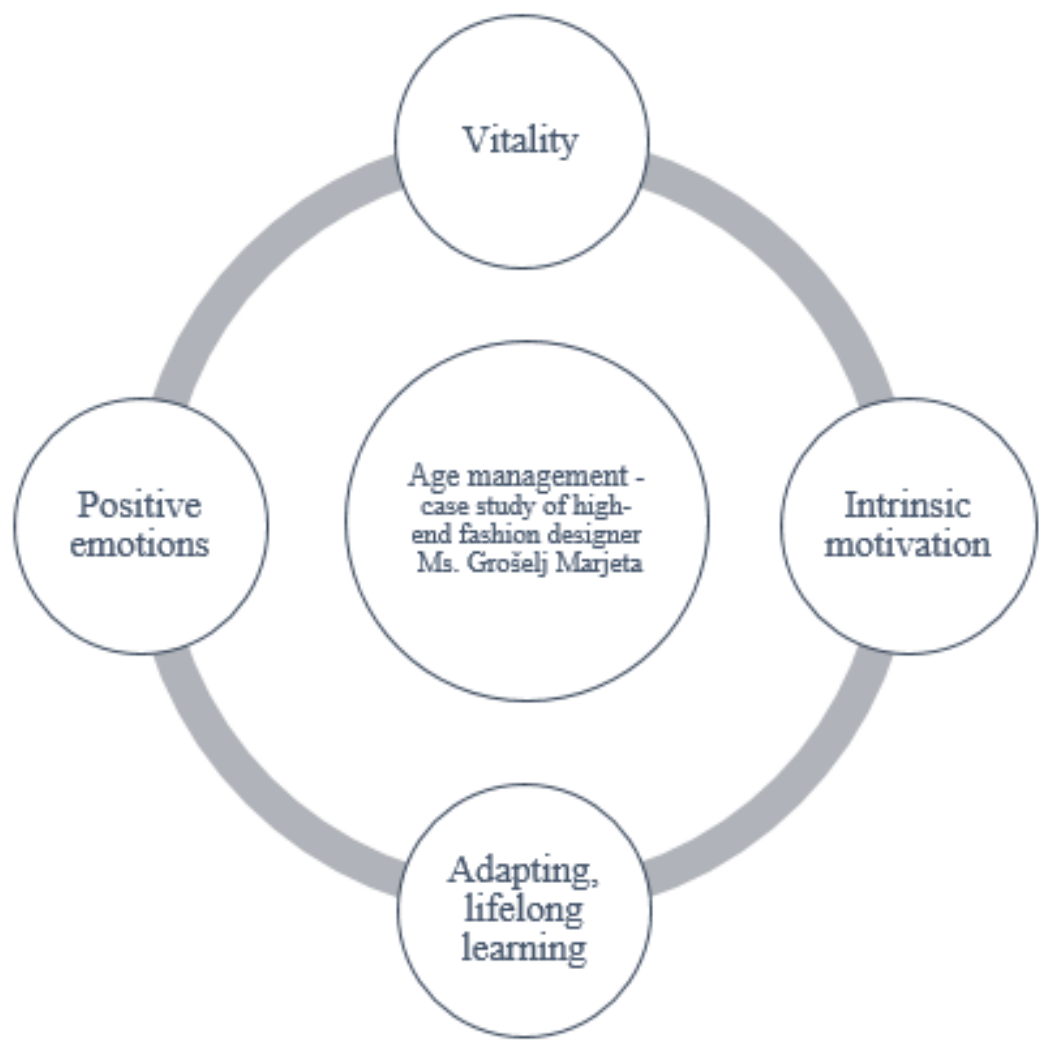

Figure 5: Conceptual model of age management in the high-end fashion industry from best practice case of Ms. Marjeta Grošelj, fashion designer

What can we learn from high-end luxury fashion designer with more than 50 years of working experience? As presented case study cannot be generalized, we hope that a lifelong approach of presented case would contribute and empower people to rethink and continue to stay active after meeting the retirement age, as well as show managers what facets to consider when dealing with age management issues. Interestingly, we noted a similarity in our case study research to the implications articulated in the practical guidance in employers' age management strategies of
European Centre for the Development of Vocational Training (2015), regarding the lifelong approach that needs to be promoted, aiming at preventive age management for workers of all age groups and guidance embedded in organization work processes. As people get older and more experienced, acquiring knowledge and skills, they increase their potential: as active contributors to the development of organizations, to the knowledge exchange between generations of workers, as mediators in innovation processes, and as participants in leadership processes. We see this as 
a major challenge for practice, to accumulate this potential of an older population, the experience of people needs to be visible and interpreted into a language which communicates to the skills needs of organizations and the qualification systems of society.

\subsection{Limitations and avenues for further research}

While we believe the presented case study has an important contribution in exploring the phenomena of age management factors in an aging society, it has two important limitations. First, our case study utilizes a single industry context from the Slovene high-end fashion industry and therefore cannot be generalized. We, therefore, encourage future researches to assess the validity and reliability of our findings in other industries and countries. Second, there is the chance that the findings of our case from Slovene high-end fashion industry are influenced by industry-specific factors. Within this study, we do not and indeed we cannot present the complete business history of Ms. Marjeta Grošelj success and her contribution to the high-end fashion industry, however, presented the story on age management raise recommendations, new ideas, as well as encourages others to learn from successful life-story of Ms. Marjeta Grošelj.

While we believe our study has important contributions, it has some limitations. It is an inductive qualitative study, analyzed by primary and secondary qualitative data of Slovenian designer of women's handbags, therefore the results cannot be generalized to the whole population, despite offering the venue for further research at organizational, inter-organizational and wider EU level. Future work will need to address above mentioned multi-level implications - individual, organizational and society level - as the European active population is aging, and we are of opinion that our findings can provide a useful groundwork. As Slovenia lacks a systematic approach for government, employers and individuals to appropriately share the cost of skills development of adult learning in addressing age-related issues in lifelong career development (OECD, 2018), we, therefore, urge future research to carefully consider sustainable financing mix for adult learning, with more targeted support for those adults, and enterprises, which stand to benefit the most from training but lack capacity to pay, should be a priority for Slovenia. Another limitation of our study is that our study presents motivation and aspiration of a self-employed business owner and age management concept as an element of human resource management, we were only able to present the perspective of a self-employed business owner. Therefore, future research should also examine older employees who work for others in the context of the age management paradigm.

Additionally, further integration of these perspectives should help researchers to develop better models that can help these people in the era of aging of population and researchers to jumpstart many other avenues for theoretical and empirical inquiry. To conclude: Ms. Marjeta Grošelj, the Slovenian luxury designer with 50 years in the world of high-end fashion, is not going to retire. She says that she will continue designing handbags for as long as her health permits because she has more than enough ideas. "The ingenuity knows no end. The work becomes easier with years, because the more you know, the more you trust yourself," said Ms. Marjeta Grošelj (Education in Slovenia, 2016).

\section{Acknowledgement}

The authors acknowledge that the paper was financially supported by the Slovenian Research Agency, Program P5-0364 - The Impact of Corporate Governance, Organizational Learning, and Knowledge Management on Modern Organization.

\section{Literature}

2TM. (2016, December 16). Slovenian Designer Marjeta Grošelj: 50 Years in the World of Fashion. Retrieved May $17^{\text {th }}, 2019$, from https://2tm.si/slovenian-designer-marjeta-groselj-50-years-world-fashion/?lang=en

Ardichvili, A., Page, V. \& Wentling, T. (2003). Motivation and Barriers to Participation in Virtual Knowledge-Sharing Communities of Practice. Journal of Knowledge Management, 7(1), 64-77. http://doi.org/10.1108/13673270310463626

Arh, T., Blažič, B. J., \& Dimovski, V. (2012). The Impact of Technology-enhanced Organisational Learning on Business Performance: An Empirical Study. Journal for East European Management Studies, 17(3), 369-383. http://hdl.handle.net/10419/84022

Arsovski, N. (2016, September 14). Marjeta Grošelj: “Oblačim se občutku primerno (I Drees According to my Feelings).”. Elle.si. Retreived May 15 $5^{\text {th }}, 2019$, from https://www.elle. si/moda/marjeta-groselj-oblacim-se-obcutku-primerno/

Berntson, E. \& Marklund, S. (2007). The Relationship between Perceived Employability and Subsequent Health. Work and Stress, 21(3), 279292. http://doi.org/10.1080/02678370701659215

Bloom, D. E., Chatterji, S., Kowal, P., Lloyd-Sherlock, P., McKee, M., Rechel, B., Rosenberg, L. \& Smith, J. P. (2015). Macroeconomic Implications of Population Ageing and Selected Policy Responses. The Lancet, 385(9968), 649-657. http://doi.org/10.1016/S0140-6736(14)61464-1

Bogataj, D., Battini, D., Calzavara, M., \& Persona, A. (2019). The Ageing Workforce Challenge: Investments in Collaborative Robots or Contribution to Pension Schemes, from the Multi-echelon Perspective. International Journal of Production Economics, 210, 97-106. $\quad$ http://doi.org/10.1016/j.ijpe.2018.12.016

Bogataj, D., Battini, D., Calzavara, M. \& Persona, A., (2017). Investments in Workplace Ergonomics from 
the Supply Chain Approach. In: Fertsch, M., Stachowiak, A., Mrugalska, B., OleskowSzlapka, J., Hadas, L., Cyplik, P., GolinskaDawson, P. (Eds.), 24th International Conference on Production Research (Icpr). Destech Publications, Inc, Lancaster, pp. 101-106.

Bogataj, D., McDonnell, D. \& Bogataj, M. (2015). Reverse Mortgage Schemes Financing Urban Dynamics Using the Multiple Decrement Approach. Springer Proceedings in Mathematics \& Statistics, 135, 27-47.

Bogataj, D., McDonnell, D. R. \& Bogataj, M. (2016). Management, Financing and Taxation of Housing Stock in The Shrinking Cities of Aging Societies. International Journal of Production Economics, /2-13. 181, http://doi.org/10.1016/j.ijpe.2016.08.017

Boumans, N. P. G., De Jong, A. H. J. \& Janssen, S. M. (2011). Age-Differences in Work Motivation and Job Satisfaction. The Influence of Age on The Relationships Between Work Characteristics And Workers' Outcomes. International Journal of Aging and Human Development, 73(4), 331-350. http://doi.org/10.2190/AG.73.4.d

Brooke, L. \& Taylor, P. (2005). Older Workers and Employment: Managing Age Relations. Ageing and Society, 25(3), 415-429. http://doi.org/10.1017/S0144686X05003466

Bucur, B., Madden, D.J. \& Allen, P.A. (2005). Age-Related Differences in the Processing of Redundant Visual Dimensions. Psychology and Aging, 20(3), 435-446. http://doi.org/10.1037/0882-7974.20.3.435

Businesseurope. (2012). Employers' Practices for Active Ageing - Final Synthesis Paper of the European Employers' Organisations Project on Age Management Policies in Enterprises In Europe. Retrieved May 20 th, 2019 , from http://erc-online.eu/ wp-content/uploads/2014/04/2013-00857-E.pdf

Calzavara, M., Battinia, D., Bogataj, D., Sgarbossa, F., \& Zennaro, Ilenia. (2019, in press). Ageing workforce management in manufacturing systems: state of the artand future research agenda. International Journal of Production Research. article: https://doi.org/10.1080/00207543.2019.1600759

Cappelli, P.(2014, November4). Engaging Your Older Workers. Harvard Business Review. Retrieved March 18, 2019, from https://hbr.org/2014/11/engaging-your-older-workers

Charmaz, K. (2011). Constructing Grounded Theory: A practical Guide through Qualitative Analysis. Los Angeles: SAGE Publications Ltd.

Crumpacker, M. \& Crumpacker, J. M. (2007). Succession Planning and Generational Stereotypes: Should HR Consider Age-Based Values And Attitudes a Relevant Factor or a Passing Fad? Public Personnel Management, 36(4), 349-369.

De Cuyper, N., Bernhard-Oettel, C., Berntson, E., De Witte, H. \& Alarco, B. (2008). Employability and Employees' Well-Being: Mediation by Job Insecurity. Journal of Applied Psychology: An International Review, 57(3), 488509. http://doi.org/10.1111/j.1464-0597.2008.00332.x

Delo. (2016, August $19^{\text {th }}$ ). Tujina da širino, dom pa ljubezen (Abroad Gives Breadth, Home Gives Love). Delo. si. Retreived May 15 $5^{\text {th }}, 2019$, from https://www.delo. si/nedelo/tujina-da-sirino-dom-pa-ljubezen.html

Dimovski, V. \& Žnidaršič, J. (2006). Od koncepta zgodnjega upokojevanja $\mathrm{k}$ strategiji aktivnega staranja (From the Concept of Early Retirement to an Active Aging Strategy). Kakovostna starost, 9(1), 2-14.
Dimovski, V., Grah, B., Colnar, S. \& Bogataj, D. (2019, in press). Age Management of Industrial Workers Based on The Multiple Decrement Modelling. IFAC PapersOnLine, to appear.

Education in Slovenia (2016, December 16 $\left.{ }^{\text {th }}\right)$. Slovenian Designer Marjeta Grošelj: 50 Years in the World of Fashion. Retrieved October 20 $0^{\text {th }}$, 2019, from https://2tm.si/slovenian-designer-marjeta-groselj-50-years-world-fashion/?lang=en

European Centre for the Development of Vocational Training. (2015). Increasing the Value of Age: Guidance in Employers' Age Management Strategies. Luxembourg: Publications Office of the European Union.

European Commission. (2019). Fashion and High-End Industries in the EU. Retrieved May 16 ${ }^{\text {th }}$, 2019, from h t t p s : / / e c. e u ropa.e u/g row th/s e ctors/fashion/high-end-industries/eu_en

European Foundation for the Improvement of Living and Working Conditions. (2006). A Guide to Good Practice in Age Management. Retrieved May 30th, 2019 from http://www.ageingatwork.eu/resources/aguide-to-good-practice-in-age-management.pdf

Eurostat. (2019a). Eurostat Database. Retrieved on 29th of May 2019 from https:/ec.europa.eu/eurostat/data/database

Eurostat.(2019b).EurostatDatabase. Retrieved on 10thofOctober 2019 from https://ec.europa.eu/eurostat/data/database

Grant, A. M. (2008). Does Intrinsic Motivation Fuel the Prosocial Fire? Motivational Synergy in Predicting Persistence, Performance, and Productivity. Journal of Applied Psychology, 93(1), 48. http://doi.org/10.1037/0021-9010.93.1.48

Grbin, B. (n.d.). Marjeta Grošelj: Torbica je postala več kot le modni dodatek [The Handbag Has Become More Than Just a Fashion Accessory]. Siol. net. Retrieved may $17^{\text {th }}$, 2019, from https://siol. net/trendi/moda-in-lepota/marjeta-groselj-torbica-je-postala-vec-kot-le-modni-dodatek-417604

Grima, F. (2011). The Influence of Age Management Policies on Older Employee Work Relationships with Their Company. The International Journal of $\mathrm{Hu}$ man Resource Management, 22(6), 1312-1332. http://doi.org/10.1080/09585192.2011.559101

Hedge, J. W., Borman, W. C. \& Lammlein, S. E. (2006). The Aging Workforce: Realities, Myths, and Implications for Organizations. Washington, DC: American Psychological Association. http://doi.org/10.1037/11325-000

Heisler, W. \& Bandow, D. (2018). Retaining and Engaging Older Workers: A Solution fo Worker Shortages in The U.S. Business Horizons, 61(3), 421430. http://doi.org/10.1016/j.bushor.2018.01.008

Hennekam, S. (2017). Thriving of Older Workers. Personnel Review, 46(2), 297313. http://doi.org/10.1108/PR-07-2015-0195

Howdon, D. \& Rice, N. (2018). Health Care Expenditures, Age, Proximity to Death and Morbidity: Implications for an Ageing Population. Journal of Health Economics, 57, 60-74. https://doi.org/10.1016/j.jhealeco.2017.11.001

Ilmarinen, J. (2012). Promoting Active Ageing in the Workplace (Discussion Paper). In: European Agency for Safety and Health at Work.

Janežič, M., Dimovski, V., \& Hodošček, M. (2018). Modeling a Learning Organization Using a Molecular Network Framework. Computers \& Education, 118, 
56-69. http://doi.org/10.1016/j.compedu.2017.11.008

Kanfer, R. \& Ackerman, P. L. (2004). Aging, Adult Development, and Work Motivation. Academy of Management Review, 29(3), 440-458.

Kontrec, A. (n.d.). Marjeta Grošelj: Modna ikona, ki ostaja zvesta svojemu slogu [A Fashion Icon who Stays True to her Style]. Cosmopolitan. Retrieved May $17^{\text {th }}$, 2019, from https://www.cosmopolitan.si/moda/marjeta-groselj-modna-ikona-ki-ostaja-zvesta-svojemu-slogu/

Kram, K. E. \& Hall, D. T. (1989). Mentoring as an Antidote to Stress During Corporate Trauma. Human Resource Management, 28(4), 493510. https://doi.org/10.1002/hrm.3930280405

Lindberg, P., Ody, C., Feydy, A., \& Maier, M.A. (2009). Precision in Isometric Precision Grip Force is Reduced in Middle-Aged Adults. Exp. Brain Res., 193(2), 213-224. http://doi.org/10.1007/s00221-008-1613-4

Lovenjak, D. (2017). »Ustvarjalnost mi pomaga ohranjati vitalnost duha [Creativity Helps Me Maintain My Emotional Vitality]«. Times.si. Retrieved May 17, 2019, from http://www.times.si/stil/moda-in-lepota/ustvarjalnost-mi-pomaga-ohranjati-vitalnost-duha--3d10981e35f1 effd4a1c84e8cde02fd9af51b821.html

Lundberg, D.\& Marshallsay,Z.(2007).Olderworkers 'perspectives on training and retention of older workers (report). Adelaide: National Centre for Vocational Education Research.

Luz, F., Leite, R. \& Alvarelhao, J. (2019). Age Management in a Formal Caregiving Organization: An Exploration of Managers' Perceptions. In C. Machado, J. Davim (Eds.) Management Science. Management and Industrial Engineering. Springer, Cham. http://doi.org/10.1007/978-3-030-13229-3 6

Miše Miklavčič, E. (2018, July $\left.6^{\text {th }}\right)$. Marjeta Grošelj v intervjuju za Reporter Magazin: Torbica ni ogledalo ženske, lahko pa zelo veliko pove o njej [Marjeta Grošelj in an Interview for the Reporter Magazine: The Handbag is not the Mirror of the Woman, But it can Tell a Lot About Her]. Reporter. Retrieved May 16 ${ }^{\text {th }}, 2019$, from https://reporter.si/clanek/magazin/marjeta-groselj-v-intervjuju-za-reporter-magazin-torbica-ni-ogledalo-zenske-lahko-pa-zelo-veliko-pove-o-njej-647736

OECD. (2018). Skills Strategy Implementation Guidance for Slovenia. Improving the Governance of Adult Learning. OECD Publishing, Paris. Retrieved May 20 ${ }^{\text {th }}$, 2019, from http://www.oecd.org/skills/ nationalskillsstrategies/skills-strategy-implementation-guidance-for-slovenia-9789264308459-en.htm

Peterlin, J., Dimovski, V., Tvaronaviciene, M., Grah, B., \& Kaklauskas, A. (2018). The Strategic Process of Developing Social Aspects of Sustainability Through the Vision Reflection in Business Education. Technological and Economic Development of Economy, 24(4), pp. 1718-1736. http://doi.org/10.3846/tede.2018.5198

Podbregar, I., Meško Štok, Z., Meško, M., \& Karpljuk, D. (2008). Stresne obremenitve na delovnem mestu managerja [Managerial Stress and the Workplace]. Organizacija, 41(2), A89-A96.

Prakash, R.S., Erickson, K.I., Colcombe, S.J., Kim, J.S., Voss, M.W. \& Kramer, A.F. (2009). Age-Related Differences in the Involvement of the Prefrontal Cortex in Attentional Control. Brain Cognition, 71(3),
328-335. http://doi.org/10.1016/j.bandc.2009.07.005

Pro Plus. (2016, May 23 ${ }^{\text {rd }}$ ). Zgodba slovenske modne legende: torbice so njen zrak [The Story of The Slovenian Fashion Legend: Handbags are Her Air]. 24ur.com. Retrieved May 16 ${ }^{\text {th }}$, 2019, from https://www.24ur.com/ ekskluziv/domaca-scena/torbice-so-njen-zrak.html

Rožman, M., Grinkevich,A.,\& Tominc,P.(2019). Occupational Stress, Symptoms of Burnout in the Workplace and Work Satisfaction of the Age-diverse Employees. Organizacija, 52(1), 46-60. http://doi.org/10.2478/orga-2019-0005

Skibinski, A., Sipa, M. \& Gorzen-Mitka, I. (2016). An Intergenerational Cooperation in the Organization - View from the Age Perspective. Procedia - Social and Behavioral Sciences, 235, 412419. http://doi.org/10.1016/j.sbspro.2016.11.051

Statista. 2019. Bags \& Accessories Report Europe. Retrieved from https://www.statista.com/outlook/358/102/bags-accessories/europe (17 May, 2019).

Shu, C. Y. (2015). The Impact of Intrinsic Motivation on the Effectiveness of Leadership Style towards on Work Engagement. Contemporary Management Research, 11(4). https://doi.org/10.7903/cmr.14043

Van den Berg, P. T. (2011). Characteristics of The Work Environment Related to Older Employees' Willingness to Continue Working: Intrinsic Motivation As a Mediator. Psychological Reports, 109(1), 174-186. http://doi.org/10.2466/01.09.10.PR0.109.4.174-186

Van der Broeck, A., De Cuyper, N., Bailien, E., Vanbelle, E., Vanhercke, D. \& De Witte, H. (2014). Perception of Organization's Value Support and Perceived Employability: Insights From Self-Determination Theory. The International Journal of Human Resource Management, 25(13), 19041918. http://doi.org/10.1080/09585192.2013.860385

Van der Heijden, B. I. J. M. \& Bakker, A. B. (2011). Towards a Mediation Model of Employability Enhancement: A Study of Employee-Supervisor Pairs in the Building Sector. The Career Development Quarterly, 59(3), 232250. https://doi.org/10.1002/j.2161-0045.2011.tb00066.x

Van der Heijden, B. I., de Lange, A. H., Demerouti, E., \& van der Heijde, C. M. (2009, May). Age as moderator in the relationship between self-versus supervisor ratings of employability and career success. In 14th European Congress of Work and Organizational Psychology, EAWOP 2009.

Vasconcelos,A.F. (2018). Older Workers as a Source of Wisdom Capital: Broadening Perspectives. Revistade Gestão, 25(1), 102-118. http://doi.org/10.1108/REGE-11-2017-002

Veingerl Čič, Ž. \& Šarotar Žižek, S. (2017). Intergenerational Cooperation at the Workplace from the Management Perspective. Naše Gospodarstvo/Our Economy, 63(3), 47-59. http://doi.org/10.1515/ngoe-2017-0018

Walker, A. (2005). The Emergence of Age Management in Europe. International Journal of Organisational Behaviour, 10, 685-697.

Yin, R. K. (2003). Case Study Research: Design and Methods (Vol. 5). Thousand Oaks, California, US: SAGE.

Žnidaršič, J. \& Dimovski, V. (2009a). Age Management: A New Paradigm in HRM within Slovenian Enterprises. The Journal of Applied Business Research, 25(3), 111-124. https://doi.org/10.19030/jabr.v25i3.1030

Žnidaršič, J. \& Dimovski, V. (2009b). Retaining Older Workers: Fields of Action - Constituting a Comprehensive Age Man- 
agement Model. The Journal of Applied Business Research, 25(4), 85-98. http://doi.org/10.19030/jabr.v25i4.1019 Žnidaršič, J. \& Dimovski, V. (2010). Reluctance towards Older Workers in Slovenia. International Business \& Economics Research Journal, 9(2), 83-100. https://doi.org/10.19030/iber.v9i2.525

Barbara Grah, is Research and Teaching Assistant, $\mathrm{PhD}$, of management and organization at the School of Economics and Business, University of Ljubljana, Slovenia. She received her Ph.D. degree in Management and Organization in 2016 from the School of Economics and Business, University of Ljubljana. Her research interests are in organization design, neuroscience implications to leadership and organization, learning organization as well as age management. Author can be contacted at barbara.grah@ef.uni-lj.si.

Ema Perme, is a senior adviser to the Minister's cabinet on adult learning and skills at the Ministry of Education, Science and Sport. She was National Coordinator for the Skills Strategy project Slovenia in cooperation with the OECD $(2015$ - 2018). She has been an appointed member from the member states to the Working Group on Adult Learning at the European Commission since 2010. Her fields of expertise are the policy of adult learning, skills development, crosssectoral cooperation, governance in adult learning. Regarding her work in practice and the development of adult learning, she is also focused on the professional development of adult educators and counsellors in lifelong learning by means of outreach activities with the aim of raising lifelong learning participation of adults.

Simon Colnar, is a PhD student at the School of Economics and Business, University of Ljubljana, where he teaches Organisation and Management. $\mathrm{He}$ graduated and received his Master's degree in Business from the School of Economics and Business, University of Ljubljana. His main research interests are: knowledge management, social work and public administration. Author can be contacted at simon. colnar@ef.uni-lj.si.

Sandra Penger, is Full Professor, PhD of management and organization at the School of Economics and Business, University of Ljubljana, Slovenia. She received her Ph.D. degree in Management and Organization in 2006 from the School of Economics and Business, University of Ljubljana. Her research interests primarily focus on management and leadership, especially authentic leadership, advanced management concepts, positive psychology, positive organizational behavior and learning organization. Author can be contacted at sandra.penger@ef.uni-lj.si. 